\title{
PRELIMENARY TRIAL FOR REARING THE SPIDER ACHAERANEA LUNATA AS A BIOCONTROL AGENT OF SPODOPTRA LITTORALIS (BIOSD)
}

\author{
AIAD, K.A. and A. M. HALAWA \\ Fruit acarology dept., Plant Protection Research Institute, ARC, Dokki, Giza,Egypt
}

(Manuscript received 7 April 2013)

\begin{abstract}
The present work was carried out to rear Achaeranea Lunata under laboratory conditions. the spider $A$. Lunata was reared on first and second instar of the cotton leafworm, Spodoptera littoralis (Boisd.). Results obtained show that incubation period of $A$. Lunata lasted 14 days .Spider individuals passed five spiderlings before reaching adult. The life cycle ranged between 102.9 and 85.3 days was for female and male,respectively. Female oviposition period was 10.6 days. The averaged of eggs per femal was 1.5 sac. Food consumption of $A$. Lunata Femal was 352.1 eggs/femal, white it was 179.3 larval /male.
\end{abstract}

\section{INTRODUCTION}

Because of mis-use of chemical pesticides, this resulted in increase the environmental hazardous of pesticides, human health hazardous, increase pesticides residue in food stuff, effect on wild life as well as farmers livestock(Theiling and crofty 1988).Because of these ,plant protection investigators work hardely to look for other safely alternatives such as insect pathogens ,plant extract, and natural enemies. Spiders have always been known to be effective predators, though their potential as biocontrol agents has not been exploited to its fullest, at least in Egypt. In addition, spiders have been found to be the most abundant group of predators in the cotton ecosystem.(Riechert and Lockley,1984).Spiders are cosmopolitan that live in many ecological environments. as predators, they play a considerable role in agroecosystem as biocontrol agents (Levy, 1998).

Members of family Theridiidae are small to medium size. They are usually found hanging upside down in an irregular web suspended on plants or hidden in rock crevices or fissures in soils (Levy,1998 and ElErksousy,2000). Many of them use very fine threads often hard to be noticed unless occasionally glitter in the sun light or covered with dust (Levy and Amitai, 1981). 
In Egypt, some species of this family were usually found in different field and truck crops and orchards. Due to its spread and importance ElErksousy,2003, El-Erksousy et al., 2006 and Hussein et al., 2003 studied the biology of three species of this family.The present work throw light on biological aspects and predation efficiency of the spider Achaeranea Lunata.

\section{MATARIALS AND METHODES}

\section{Rearing technique:}

Experiment was carried out under laboratory conditions $\left(27 \pm 2^{\circ} \mathrm{C}\right.$ and $70 \pm 5$ R.H.\%).Achaeranea Lunata individuals were collected from citrus trees at Beni-sueif. governorate, using sweep net technique. Individuals were transferred to laboratory. The individuals were examined directly by using steromicroscop .taxonomical key used for identification (Jones, 1983).Newly emerged adult female and male were confined together in a test tube $(20 \mathrm{~cm}$ long and $0.5 \mathrm{~cm}$ in diameter), closed with cotton pad and supplied daily with prey. The female was noticed daily until laying the egg sac and hatched spiderlings. Each spiderling was isolated separately in a test tube together with surplus numbers of prey individuals and noticed till reaching adult stage. 1st and 2nd larval instars of the cotton leafworm, Spodoptera littoralis (Boisd.) were used as food through the life span. The numbers of consumed prey individuals were recorded daily and replaced by fresh ones. Behaviour and some biological aspects were also recorded.

\section{RESULTS AND DISCUSSION}

\section{Feeding behavior:}

When the predator $A$. Lunata noticed the prey, it usually comes close and moves around it for few seconds, then catched it between its chelicerae by the help of the front legs. Embeding its chelicerae in the prey, the predator starts to suck prey contents. The predator abdomen becomes enlarged and usually rests for few minutes before searching again for another one..

\section{Mating :}

\section{1-Preparing period}

The virgin female stayed for about 9 days as a premating period. The male was firstly placed in the test tube and then followed by the female. The latter started to come close to the male in relative movements for about 2 
minutes. The male came close to it, moving his front legs up and down and pedipalps alternatively. it then touched the tips of the front female legs and pidipalps, before the beginning of copulation. Both sexes female and male must pass through the preparing period before copulation occurs. Otherwise, the female refuses the male threatening by its chelicerae to enforce male to move away.

\section{2-Copulation}

The male holds the female using its first pair of legs, leg I to hold her leg II, and his leg II to hold her leg III. it then inserts his right palp into the female genital opening. The sperms are transferred in female seminal receptacles. The mating process continued for about 1-2 minutes, then the male escaped away.

\section{Development of stages:}

\section{Eggs}

Each egg sac contained with average $34.3 \pm 4.3$ egg as shown in (Table 1). incubation period for both spider female and male was 14 days under laboratory conditions of $27 \pm 2^{\circ} \mathrm{C}$ and $70 \pm 5$ R.H.\%

\section{Spiderling duration and food consumption}

The spider females and males have five spiderlings stages .The fifth spiderling was shorter in their duration than other spiderlings in both females and males, it averaged 5.3 and 4 days, respectively as shown in (Table 1) The duration of 1st, 2nd, 3rd, 4th and 5th spiderlings averaged $37.2,23.2$, $14.3,8.8$ and 5.5 days for female respectively and $29.1,19.6,11.2,7.4$ and 4 days for male, respectively. Total female spiderlings duration were longer (88.9 days) comparing with the males spiderlings duration ( 71.3 days).

The food consumption of the spiderlings increased with the spiderlings growth as shown in (Table 1). The first spiderling of both female and male consumed about 114.6 and 58.3, prey/spiderlings/day for female and male,respectively .The value gradually increased depending upon the spiderling growth, for example the second spiderlings consumed about 93 and $37.3 \mathrm{prey} / \mathrm{spiderlings/day}$ for female and male,respectively. On the other hand, the fifth spiderling consumed about 58.1 and 21.2 prey/spiderlings /day for female and male, respectively. The total food consumption of the female spiderling was 352.1 prey / spiderlings / day, while male was 179.3 prey / spiderlings / day. 


\section{Adult longivity}

as shown in (Table 2) During the oviposition period, the spider female deposited about 1.5 egg sacs . preovipostion, ovipostion and postovipostion per femal durated $7.7,10.6$ and 4.7 days while male longivety durated 21.1 days.The adult female devoured an average of 78.9 , 114.9 and 23.9 prey per female pre-ovipostion,ovipostion and post-ovipostion respectively while male devoured an average of 140.6 preys during longevity. The female stopped their feeding about one day after the preovipostion and began to web the egg sac by her spinnerets and deposited the eggs with covered it by layer of dense silky webbing .

Table 1. Spiderlings duration and food consumption of the spider Achaeranea Lunata female and male when fed on the newly hatched larvae of $S$. littoralis at laboratory conditions

\begin{tabular}{|c|c|c|c|}
\hline Spider stages & Sex & $\begin{array}{c}\text { Average duration in } \\
\text { days }\end{array}$ & $\begin{array}{c}\text { No. of devoured prey } \\
\text { individuals }\end{array}$ \\
\hline $\begin{array}{c}\text { Number of egg } \\
\text { sac/female }\end{array}$ & & $1.5 \pm 0.55$ & \\
\hline $\begin{array}{c}\text { Total number of } \\
\text { eggs/Sac }\end{array}$ & & $34.3 \pm 4.5$ & \\
\hline \multirow[t]{2}{*}{$1^{\text {st }}$ spiderling } & q & $37.22 \pm 2.9$ & $114.6 \pm 8.8$ \\
\hline & $\hat{0}$ & $29.1 \pm 2.1$ & $58.3 \pm 3$ \\
\hline \multirow[t]{2}{*}{$2^{\text {nd }}$ spiderling } & $q$ & $23.22 \pm 0.8$ & $93 \pm 3.2$ \\
\hline & $\hat{0}$ & $19.6 \pm 1.2$ & $37.3 \pm 2.9$ \\
\hline \multirow[t]{2}{*}{$3^{\text {rd }}$ spiderling } & 오 & $14.3 \pm 0.7$ & $42.7 \pm 2.3$ \\
\hline & $\hat{0}$ & $11.2 \pm 0.9$ & $33.7 \pm 1.7$ \\
\hline \multirow[t]{2}{*}{$4^{\text {th }}$ spiderling } & 우 & $8.8 \pm 0.4$ & $43.8 \pm 1.9$ \\
\hline & $\hat{0}$ & $7.4 \pm 0.5$ & $28.8 \pm 2.2$ \\
\hline \multirow[t]{2}{*}{$5^{\text {th }}$ spiderling } & 오 & $5.3 \pm 0.5$ & $58.1 \pm 3.7$ \\
\hline & $\hat{0}$ & 4 & $21.2 \pm 1$ \\
\hline \multirow[t]{2}{*}{ Total spiderling } & 우 & $88.9 \pm 2.5$ & $352.1 \pm 17$ \\
\hline & $\hat{0}$ & $71.3 \pm 2.6$ & $179.3 \pm 6.7$ \\
\hline \multirow[t]{2}{*}{ Life cycle } & q & $102.9 \pm 2.6$ & $352.1 \pm 17$ \\
\hline & $\hat{0}$ & $85.3 \pm 3.2$ & $179.3 \pm 6.7$ \\
\hline
\end{tabular}


When female of Anelosimus aulicus (Koch) of family theridiidae was feeding on Aphis, Aphis craccivora,passes through five spiderlings and laid an average of $8.6 \mathrm{egg}$-sacs (Hussein et al .,2003)

Putman (1967) described the life cycle of Philodromus praelustris Keyserling (Family: Philodromidae). Females produced up to 12 egg sacs containing a total of over 299 eggs in insectory ,but the later eggs did not hatch.

During the oviposition period, the females deposited 6.3 sac/female, each egg-sac contained about 31.1 eggs, the incubation period was 16 days. The spider females passed life cycle and life span longer than males. Also, the females consumed individuals of prey higher than males during life cycle and life span.

Table 2. Adult female longevity and fecundity of Achaeranea Lunata when fed on the S.littoralis at laboratory conditions

\begin{tabular}{|c|c|c|}
\hline Biological aspects & Duration (day) & $\begin{array}{l}\text { Food consumption } \\
\text { (prey/spiderling/day) }\end{array}$ \\
\hline Pre-ovipostion & $7.7 \pm 0.7$ & $78.9 \pm 6.8$ \\
\hline Ovi-postion & $10.6 \pm 0.7$ & $114.9 \pm 6.3$ \\
\hline Post- ovipostion & $4.7 \pm 0.7$ & $23.9 \pm 2.3$ \\
\hline Adult longevity & $\circ$ & $22.9 \pm 1.4$ \\
\hline & 0 & $21.1 \pm 4.5$ \\
\hline Life span & + & $125.8 \pm 2.9$ \\
\hline & 0 & $106.4 \pm 3.6$ \\
\hline
\end{tabular}

\section{Life span}

As shown in (Table 2) obtained results cleared that the spider female life span durated 125.8days, while the duration of spider male life span was 106.4 days. On the other hand, during this period, the spider female consumed about 569.8 prey /female this value decreased to 319.9 prey /male. The food consumption depends on both spiderlings and adult stage .The spider male less efficiency than female ,therefore, female devoured 1.78 times than male during life span. 


\section{REFERENCES}

1. Dick Jones. 1983. The country life guide to spider of pertain and nourthren Europe . country life books $320 \mathrm{pp}$

2. Dinter, A. 2004. A mass rearing method for the linyphiid spider species Erigone atra (Blackwall) (Araneae: Linyphiidae). J. Appl. Entomol., 128 (3): 200-203.

3. El-Erksousy, M. H. 2000. Studied on some true spider in Egypt .Ph.D. Thesis, Fac. Of Agric., Al-Azhar Univ. 130 pp.

4. El-Erksousy, M. H. 2003. Biology of the spider Theridion egyptium Fawzy \& ElErksousy fed on Spodoptera littoralis larvae. Bull. Ent. Soc. Egypt, 80:229233.

5. El-Erksousy, M. H. and R. M. Amer. 2007. Biological and predation studies on the predaceous spider, Steatoda triangulosa (Walckenaer) fed on the pink bollworm, Pectinophora gossypiella (Saund.). Egypt, J. Agric. Res., 85 (5): 1599-1611.

6. El-Erksousy, M. H, Shoeib,Ameira M. and Gomaa, Wafaa, O. 2006. Biological of the spider, Steatoda triangulosa (Walckenare) fed on larvae of Spodoptera littoralis (Boisd). $2^{\text {nd }}$ Conf., On Farm. I.P.M. 16-18. Jan., :256-259.

7. Hussein, A. M., M. F. Hassan and N. F. R. Ahmed. 2003. Biological aspects of Anelosimus aulicus (C.L. Koch, 1838) (Arachnida : Araneida : Theridiidae) in Egypt. Serket, 8 (4): 129-134.

8. Levy, G. 1998. Fauna Palestine. Arachnidae, Araneae: Theridiidae. The Israel academy of sciences and Humanities. $225 \mathrm{pp}$.

9. Levy, G. and Amitai, P. 1981.The spider genus Enoplogntha (Araneae : Theriidae) in Israel. Zool. J. Linn. Soc., 72:43-67.

10. Putman, W. L. 1967. Life histories and habits of two species of Phiodromus (Araneid : Philodromidae) in Ontario. Can. Entomol., 99: 622-631.

11. Riechert,S.E. and T.Lockley. 1984. Spiders as biological control agents.Ann.Rev.Entomol.29:29-32.

12. Theiling,K.M. and B.A. croft. 1988. Pesticide side-effects on arthropod natural enemies: a data base summary Agric Ecosyst.Environ. 21:191-198. 
تجربة مبائية لتربية العنكبوت Achaeranea Lunata (CLERK 1752) كعنصر مكافحة حيوية لاودة ورق القطن خالد عبد العزيز عياد وعلاء حلاوة معهُ بحوث وقاية النباتات - مركز البحوث الزراعية - الدقي - جيزة - مصر تم تربية المفترس العنكبوتى Achaeranea Lunata على يرقات العهــر الأول لــدودة

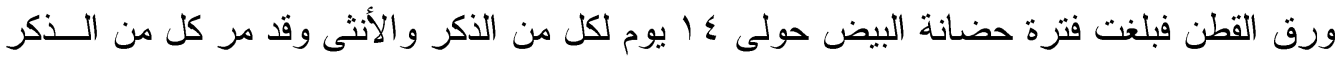

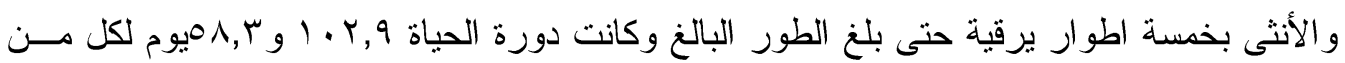

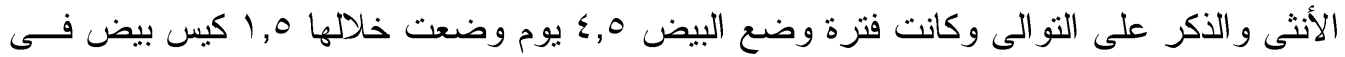

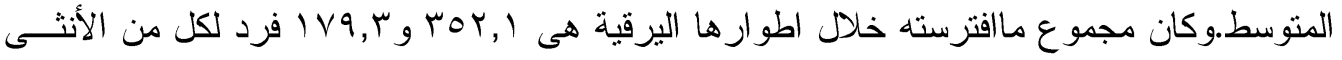

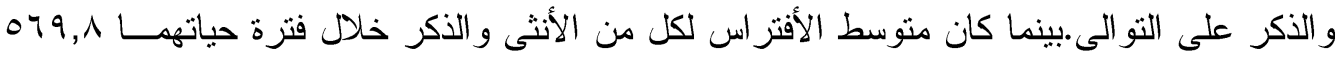
و 9,9 اس على التزتييز 